\title{
Revitalization of Funding for Savings and Loans Cooperatives As Efforts To Improve The State's Economy After The Covid-19 Pandemic
}

\author{
Hassanain Haykal ${ }^{1}$; Theo Negoro ${ }^{2}$; Livany Adeline ${ }^{3}$ \\ ${ }^{1}$ Faculty of Law, Maranatha Christian University, \\ ${ }^{2}$ Faculty of Law, Parahyangan Catholic University, \\ ${ }^{3}$ Faculty of International Business, Ajou University. \\ Corresponding author's email: hassanain.haykal@law.maranatha.edu;
}

\begin{tabular}{l}
\hline Article Information \\
\hline Submitted : April 16, 2021 \\
Reviewed : July 26, 2021 \\
Accepted : August 11, 2021 \\
Keywords: \\
cooperative financing; law; \\
organizational revitalization. \\
DoI: 10.20961/yustisia. \\
v10i2.50438
\end{tabular}

\begin{tabular}{l} 
Abstract \\
This research aims to analyze the government's possible \\
strategies to empowering cooperatives as an alternative means of \\
channeling financing after the Covid-19 Pandemic in Indonesia. \\
Basically, cooperatives are business media for enhancing the \\
standard of living in a family, and are referred to as the pillars \\
of the national economy. The study was also carried out in order \\
to provide a regulatory solution regarding the revitalization \\
of cooperatives, in strengthening the organisation, especially \\
in the financial aspect. The normative juridical approach, was \\
used, also known as the doctrinal legal technique. The results \\
showed that the cooperatives required significant organizational \\
changes, such as strengthening the implementation of good \\
governance regulations, conducting financial agreements, as \\
well as managing income and human resources. Furthermore, \\
significant organizational changes were achieved by forming \\
a ministerial regulation, to regulate good governance, enact \\
internal rules, create a code of conduct, and establish a financial \\
system with legal agreement among the cooperative members. \\
\hline
\end{tabular}

\section{Introduction}

The implementation of micro and macroeconomic theories is essential in improving the effective management of a state's resources. This is due to their respective functions in providing solutions to difficult economic situations. In microeconomic theory, the fundamental techniques required to achieve consumer satisfaction and the efficient use of existing resources are greatly considered (Sukirno, 2002). Meanwhile, the determination of economic activities, as well as the importance of government policies and intervention are emphasized in macroeconomic (Sukirno, 2020). Based on these two theories, the state 
needs to synergize several strategies, such as increasing the capital income reducing the poverty and unemployment rate, and elevating the educational sector to reduce the high level of illiteracy. The factors that need to be synergized are closely related to the characteristics of developing countries, such as Indonesia (Todaro, 1999). For instance, elementary attributes need to be resolved by developing an educational system, capable of reducing the illiteracy rate and developing social aspects. However, to further boost this sector, it is necessary to increase the people's per capita income.

The inability to improve the economy of a state leads to a gap, which needs to be filled by the Indonesian government, through the banks' financing policies. This is in accordance with the study of Danil Syahputra and Supiah Ningsih, which stated that "... in the last 10 (ten) years, conventional and sharia banking credits had continued to increase yearly within Indonesia (Syahputra and Ningsih, 2020). With the increase in conventional and sharia banking credits, Indonesia also experienced a fluctuating economic growth that gradually developed by $4.5 \%, 6.1 \%$, and $6.03 \%$ in 2009,2011 , and 2013 , respectively. This growth subsequently decreased by $5.56 \%, 5.01 \%$, and $4.88 \%$ in 2013,2014 , and 2015, respectively. It also experienced a positive trend at 5.03\%, 5.07\%, 5.17\%, and $5.02 \%$, in 2016, 2017, 2018, and 2019, respectively, with a drastic decrease of $-2.07 \%$ in 2020 (Bank Indonesia, 2020).

The economy of the state in 2020 was worrisome, despite having a downward trend with a concrete basis. Based on data from the Indonesian Central Statistics Agency (BPS), the per capita income of the people has decreased by IDR 286,000 (two hundred eighty-six thousand rupiahs) or $2.53 \%$ since the inception of the Covid-19 Pandemic (CNN Indonesia, 2020). Furthermore, the decreased income caused a $0.02 \%$ increase in the Indonesian Human Development Index (HDI), from 71.92 to 71.94 in 2019 and 2020 , respectively. This is because the income of people is significantly affected due to the pandemic, and also with the present focus of the government on the allocation of budgets to tackle the virus (CNN Indonesia, 2020). Based on the data above, the Covid-19 pandemic is the main cause associated with the increasing difficultly experienced by communities, in order to develop their social and educational aspects. This is due to their incomes focusing more on meeting food needs. I'm addition, the present conditions of Indonesia are a problem described in the analysis of macroeconomic theory, due to its scope being already at the level of the economic function state's economic function and the way the economy works (Sukirno, 2020).

The experts further stated that the strengthening of a state's economy achieved significant benefit when supported by similar regulations, especially those associated to the finances of people, based on micro, small, and medium enterprises (MSMEs). The GDP of the state at IDR 8,573 trillion and 117 million workers are contributed by MSMEs, indicating that this sector needs adequate support (Purwanto, 2021). However, the study of Arin Ramadhiani Soleha, stated that the business turnover of MSMEs had decreased due to the Covid-19 pandemic. Approximately $63.3 \%$ of business actors experienced a decrease less than $30 \%$, while $2.2 \%$ and $1.6 \%$ had an increase of below and above $30 \%$, respectively. In addition, the remaining $0.6 \%$ did not experience any significant business turnover changes (A.R. Soleha, 2020). 
Being one of the major aspects of a country's legal system was the main reason regulation was selected as an appropriate solution, in order to help improve the economy during the aftermath of the pandemic. This is based on the Lawrence Friedman's theory of a legal system, which included constitutional substance, structure, and culture (Friedman, 2001). Moreover, regulation falls into the category of legal substance, which is a reflection of the normalized values living or needed in the society (Gillissen and Gorle, 2005). Therefore, this regulatory solution for MSMEs is the starting point for Indonesia, in order to restart and fill the gap from the economical decline due to the Covid-19 Pandemic. The experts further states that the regulations suitable for financing micro, small, and medium enterprises are used to strengthen non-bank financial institutions, which plays a strategic role in meeting the capital of MSMEs (lower class economies). These includes the revitalization of finances and activation of MSMEs cooperatives.

The minimal contribution of cooperatives presently underlies the problems of Indonesia, due to a lack of high-efficiency power to support the improvement of the economy after the pandemic. According to the 210 cooperative thousand units in Indonesia, $70 \%$ are active, with $<50 \%$ highly contributing to the society, especially the MSMEs. Teten Masduki (Minister of Cooperatives and Small and Medium Enterprises from 2014-2019), stated that "The UN recorded an average $16.31 \%$ of the world's population as members of cooperatives. However, the participation rate in Indonesia was still unfortunately lower at around 8.41\%" (RM.Id, 2021). Teten further stated that the Indonesian economy was $0.97 \%$ in 2019 , relatively lower than the average contribution of cooperatives to the world economy by $4.30 \%$ (RM.Id, 2021).

According to the post 2015 of International Monetary Fund agenda on the sustainable development goals, there was a pronounced need to ensure that available resources were used more effectively. It also stated that additional financing were accessed from private and various sectors, without reliance on traditional fundings, such as bank and other conventional public institutions (International Monetary Fund, 2015). Furthermore, cooperatives are one of the shape of financial institution without a full banking capacity, causing the inability to perform saving deposits. Meanwhile, they provide an alternative financial services such as contractual savings, as well as micro-loan and venture capitalists (Rateiwa and Aziakpono, 2017).

There are weaknesses in the non-bank financing system in Indonesia, due to the inefficiency of cooperatives. This is because the provided cooperative finances has significant differences with the bank, especially from the low interest rate and easy disbursement of funds, considering the financial distribution available to its members. Therefore, this indicates that MSMEs should be able to select cooperatives as an alternative form of financing, compared to banking institutions. Meanwhile, other facts show that cooperatives in Indonesia do not yet have the suitable legal design to conduct a financing system, which protects them and their members. In addition, the government, academics, and practitioners engages in financing need, in order to revitalize the role of cooperatives in Indonesia. They also help to generally improve the economy of a state and increase the income of people, to confront the challenges caused by the Covid-19 Pandemic. 
This research has similarities and differences with other preliminary studies, such as Sudiana, Syamsul Alam, and Jopang, "Revitalizing Cooperative Management to Realize the Welfare of Cooperative Members (Study at the Muna Regency Cooperative and SME Service)", published in the PUBLICUHO Journal, Faculty of Social and Political Sciences at Halu Oleo University. The study explained the revitalization that focused on human resource management, in the Natuna Regency Cooperative, by implementing empowerment. This was also associated with the provision of capital assistance and facilities, conducting mappings for inactive to active institutions, and providing several obstacles in the implementation of cooperatives in Natuna Regency. These obstacles include, (1) Lack of capital, (2) The absence of awareness to repay the loan money for its members, (3) Incomprehensive cooperative regulations in Muna Regency and 4) Inadequate public understanding on Village Unit Cooperative (KUD).

Based on the study, the similarity was in the concept of revitalization for legal subjects (cooperatives). However, the scope of the research was based on Cooperatives in Muna Regency and Revitalization of Cooperative Management. The most fundamental difference of the study was that it examines the revitalization within the concept of funding carried out by cooperatives, to support the capital of business actors (MSMEs in particular and the community in general) and improve the national economy after the pandemic.

The similarities and differences continues with other studies by Jatmiko Wahyudi, Aeda Ernawati, and Siti Qorrutu Aini "Revitalization of Village Unit Cooperatives With No Status Active: Case Study in Pati Regency", published in the Maksipreneur Journal of Management, Cooperative, and Entrepreneurship, Faculty of Economic at Proklamis 45 University. The research explained the revitalization that focused on reviving the village unit in Pati Regency, through the implementation of radical strategies such as disbanding ineffective cooperatives and injecting more resources into active non-bank systems.

The similarity with this study is in the revitalization concept for legal subjects? cooperatives). However, the scope of the research is based on cooperatives in Pati Regency, and the radical strategy to the effectiveness of the active cooperatives.

The urgency of this study originates from the need of people for alternative financing with high flexibility, which is protected by the state. It also has philosophical aspects that supports their struggle, to obtain an increase in their welfare and escape poverty. These factors are basically in the aspect of Savings and Loans Cooperatives. At this time, several laws and regulations discussing the finances are observed, such as those contained in the Minister of Cooperatives and MSMEs Number 15/Per/M.KUKM/2015 Regulations, concerning Business Savings and Loans by Cooperatives. However, there are no regulations specifically governing the process of revitalization. Therefore, an effort is needed to reactivate the financing of the savings and loans cooperatives through legal instruments, to maintain the spirit of membership and community protection.

\section{Research Methods}

This study used the normative juridical approach (Peter Mahmud Marzuki, 2014), often referred to as the doctrinal (Zainudin Ali, 2015) or normative legal method (Soetandyo Wignjosoebroto, 2002). The primary materials were obtained from the 1945 
Indonesian Constitution, the Civil and Commercial Codes, as well as Law Number 25 of 1992 on Cooperative. The secondary materials were also obtained from library samples and informative documents on legal products, which provided additional data, legal expert opinions, and scientific articles related to the study. The obtained data were qualitatively and descriptively analyzed, as the tertiary material was collected from the legal, English-Indonesian Dictionaries, and vice versa.

\section{Research Result and Discussion}

\section{A. Overview of Cooperatives}

Although the efforts of cooperatives were presently decreasing due to the pandemic, they were still considered very effective in sustaining the economy of the state. As a movement, this was due to the economic philosophy balancing the capitalistic system developed in the European Continent, when the industrial revolution occurred (E.G. Nurse, 1922). This movement originated with three "Fundamentals" that were generally responsible for constituting the theoretical basis of their practical success, as follows (E.G. Nurse).

a. Increased efficiency or reduced costs of service: no credit, solicitation, and gratuitous or nominally paid service to members.

b. Popular distribution of savings or profits: minimum interest paid to invested capital, surplus as patronage and wage dividends.

c. Democratic control, which allows each member to vote as an individual.

The study of Mohammad Hatta, stated an idea that included the elements of democracy, mutual cooperation, and self-help organization, which was further known as the "Pancasila Democratic Economic System" (Z.A. Hoesein, 2016). This system philosophically needed an economic improvement originating from the bottom to the up, as outlined in Article 33 paragraph (1) of the Indonesian Constitution, which stated that "The economy was structured as a joint effort based on the principle of kinship."

The Pancasila democratic economic system is a concept that combines democracy and society, which is the core of Article 33 paragraph (1) of the 1945 Indonesian Constitution. Therefore, the cooperative and the Pancasila democratic economic system were inseparable from the concept of people's welfare. These cooperatives played vital roles in the economic growth of Indonesia.

The understanding of cooperatives was in accordance with the Black's Law Dictionary, which stated that "A corporation or association was organized for purposes of rendering economic services, without gain to itself, shareholders, or members. Type of business owned by its member-customer" (H. Campbell, 1991). Therefore, a cooperative was a business operating in the economic sector, with profits generated only for the management. According to the experts, "a business owned by its members" is defined as a cooperative formed to increase the value of welfare, while also eradicating poverty.

The cooperative entity existed as a symbol of the struggle for lower-class economies, due to having various businesses aimed at improving the living 
standard of their members. Furthermore, International Cooperatives Alliance defined cooperative as an organization generally established for the welfare of members and the society, due to having values on self-help and responsibility, democracy, equality, and solidarity (International Cooperatives Alliance, 1995).

These organizations were classified based on various criteria in Indonesia, such as functions and arrangements, which contained the Producer, Consumer, and Marketing cooperatives. This was in accordance with Article 1 paragraph 17 of the Minister of Cooperatives and Small-Medium Enterprises Regulation Number 10/Per/M.Kukm/Vi/2016. It also contained service cooperatives, as shown in Number 01/Per/M.Kukm/I/2016 on the Service Unit for the Procurement of Goods/Services, as well as Savings and Loans (Government Regulation Number 91995 on the Implementation of Savings and Loans Business Activities by Cooperatives).

According to the experts, Savings and Loans Cooperatives were vital in improving the economy of countries affected by the Covid-19 Pandemic. They acted as an alternative for MSMEs, due to flexibility in providing finances, such as tenor, loan interest, and the credit extended amount. The financing provided by the cooperative was "Self-help," which was associated with helping organizational members, leading to an increase in flexibility.

\section{B. The Meaning of Cooperatives in Indonesia}

According to Article 33 paragraph (1) of the 1945 Indonesian Constitution, the aim of cooperatives was to prosper and help alleviate the economy of members. They also reminded everyone that the economy of Indonesia was solely formed for the economic welfare of its people. Therefore, Indonesia affirmed its natural perspective on cooperatives as the "pillars" of the nation's economy, which played a significant role in strengthening the fundamentals of the state. This was to prevent the economic system from eroding the values of kinship, Pancasila democracy, and mutual cooperation previously strengthened by cooperatives.

Cooperative originated from the word "Co", which represented "Together", and "Operation (work)", and further translated as "working together" (Sitio and Tamba, 2001). However, the definition was adjusted in Indonesia, by considering their important roles. Furthermore, Law Number 25 of 1992 defined cooperatives as legal entities that contained people, with Michelsen, stating that it was an organization where the members acted as users and owners of the business (Michelsen, 1994).

Mohammad Hatta, as quoted from Revrisond Baswir (2000: 2), stated that "Cooperatives were established as unions of the weak, to defend their daily needs with the aim of reaching the necessities of life at the cheapest cost. In cooperatives, mutual needs were prioritized over profits." Furthermore, Munker, as quoted from Arifin Sitio and Halomoan Tamba, defined cooperatives as "mutual help" organizations conducting commercial affairs in groups, based on the concept of intimate cooperation (Sitio and Tamba: 18). 
Based on Indonesia legal association perspectives, a cooperative represented a group of collaborations containing entities that provided freedom to the economic development of members. Furthermore, Anoraga and Djoko (2002) defined it based on kinship and mutual cooperation, stating cooperatives as the economic movement of the people. They further stated that it was a form of appreciation from community members, aimed at defending their economical rights to avoid eroding competition from other advanced systems. This was based on the prioritization of profits, as part of their business objectives. Therefore, cooperatives' objectives in terms of kinship and mutual cooperation were protected by the Indonesian Constitution, as well as strengthened through laws and regulations.

SOEs and private companies played a different role as business entities in the Indonesian economy, with the struggle for welfare and economic education remaining in the domain of the cooperatives. In normative juridical terms, the roles of cooperatives were stated in Article 4 of Law Number 25 of 1992 as follows,

a. Build and develop the potential and economic capacity of members and society, in order to improve socio-economic welfare.

b. Actively develop efforts to enhance the quality of human and social life.

c. Strengthen the economy as the basis for the strength and resilience of the nation, with cooperatives as the pillar.

d. Create and develop a joint national economy, based on kinship and economic democracy principles.

Cooperatives are philosophically the "backbone" of the state's economy, with their roles also embodied in Article 17 paragraph (1) of Law Number 25 of 1992. This stated that cooperatives were owners and users of the services. Therefore, the success, failure, development, decline, progress, and withdrawal of the organization depends on its members. This was because their participation positively affected the economy of Indonesia. Active member participation also led to the creation of good, effective, and efficient management, in order to achieve the goals of the organization. When the participations of several members were active, the pressure from other organizations increases, especially the noncooperatives. Therefore, there was an automatic increase in making members more active in cooperative participations.

An essential attribute in conducting cooperative management was observed when each member carried out the Cooperative's Bylaws, while also providing services according to the needs of those bigger than their competitors. Furthermore, financing was a type of cooperative relevant to the Savings and Loans. The activities carried out by this cooperative involved the collection of funds from members, and channelling them back to the concerned association (Anoraga and Djoko). Therefore, the focus of cooperative scope that needs to be revitalized was those with business units in the savings and loan sector. 
This explanation showed the importance of cooperatives to the economic system in Indonesia. Therefore, cooperatives were used as a basis for determining state legal instrument in Indonesia. This guaranteed the rights and obligations of the community to obtain a decent life, especially in improving their economy after the Covid-19 Pandemic. The concept also made cooperatives a tool, in order to enhance the economy of the state through the bottom to up method, which involved strengthening the fundamentals that affected the wider community.

\section{Relevance of Cooperatives and Micro, Small and Medium Enterprises (MSMEs)}

MSMEs play an important role in enhancing a state's economy, as they are top ranked in terms of equity. This is because they are established in various parts of the state, due to the ease in deposited capital. Furthermore, MSMEs are the biggest contributor to the reduction of unemployment and poverty in Indonesia. Its important role is basically re-optimized when supported by cooperatives, as an alternative to financing. This process is carried out through savings and loan activity units, as supporting and struggling entities for the community, to improve welfare and eradicate poverty. Till now, MSMEs still relied on a system of channeling funds in credit, from banks that basically did not have high flexibility than cooperatives. These conditions created options for MSMEs not willing to borrow from banks, to independently strengthen their capital to a certain amount, based on the development of business activities. According to the experts, this created a weak business climate in terms of capital foundations, and created an ineffective organizational structure.

Based on the grass root economic business, the MSMEs reached the various types of organizations. According to Katherine C. Deville. et.al., cooperatives contributed to reducing poverty and unemployment, as well as improving the welfare of people (Deville et.all, 2007). Therefore cooperatives became the alternative methods used by MSMEs, to receive training on business activities and finance, through Savings and Loans. Cooperatives are a sources of struggle and resistance to the elimination of poverty, as well as improvement of human welfare and living standards. Meanwhile, MSMEs are a business model having high innovative power without requiring large capital. This was often due to the forward movement to prevent the products/services offered from eroding times or other business actors.

Based on varying models, cooperatives also had business capital collected from the principal savings, through the mandatory deposits of their members. However, this process was not only limited to Savings and Loans Organization (KSP), with others including Marketing (focuses on market products produced by their members), Producers (aims to develop innovation and technology for the production of goods from members), and Employee (bring together employees to develop their skills) Cooperatives. In addition, MSMEs used these 
types of cooperatives to develop their business models, as they do not depend on banks or wait a long time.

A relationship needs to exist between Cooperatives and MSMEs, especially in improving the economy of a state. This enabled the state to create beneficial regulations for both organizations. Manullan (2007), stated that cooperatives and SMEs need to obtain a larger portion of the regulation, in order to create legal certainty, benefits, and justice. These regulations were solely aimed at improving the economy of the state.

Besides Law Number 25 of 1992, other roles of cooperatives were observed from a macroeconomic perspectives, which was often simultaneous with MSMEs (Afriandy, 2020) as follows.

a. Carrying out its position as a major player in various sector of economic activities,

b. Providing the largest employment opportunities in Indonesia,

c. Developing local economic activities and community empowerment,

d. Creating new markets and the newest sources of innovation.

\section{The Concept of Financing for Savings and Loans Cooperatives in Indonesia}

Financing for Savings and Loans Cooperatives in Indonesia is better known as the concept of "Fund distribution", which was contained in Article 19 of the Minister of Cooperatives Regulation. It was also contained in MSMEs Number 15/Per/M.KUKM/2015 concerning Business Savings and Loans by Cooperatives. The Ministry of MSMEs Regulation stating the scope of business activities for savings and loans includes, 1) Collecting savings from members, 2) Providing loans to both full-time and prospective members, and 3) Managing the balance of funds and loan distribution sources (Azhari, 2017).

These scopes were part of the business activities of a Savings and Loans Cooperative in Indonesia. Furthermore, the organization showed its flexibility in channeling funds to the community, through the provision of loans to "Prospective cooperative members." This indicated that people were considered as legal subjects capable of enjoying the cooperative benefits, when using the phrase. In addition, this was in line with Article 4 of Law Number 25 of 1992 concerning Cooperatives.

The Ministry of Cooperatives and MSMEs Regulation also provided legal certainty, in order to guarantee the rights and obligations of the prospective member. This indicated that the prospective member was obliged to eagerly become a full-time user. It was also carried out to prevent the cooperative from plunging into a public fund-collecting institution, such as bank.

This distinction between cooperatives and banks was a point that often distinguished the terms used in business activities. For example, the term distribution of funds was known as "Credit" and "Loans" in Banking Laws and cooperative, respectively. This term was used because cooperatives distributed

$132 \quad$ Yustlsla Volume 10 Number 2 (May-August 2021) $\quad$ Revltallzatlon of Fundlng for Savings and... 
funds to members and not the public, making it inappropriate to use the word "credit".

The process of borrowing conducted by the cooperative needs to be basically based on an agreement, in accordance with its business activities. Badrulzaman (1994), stated that a Loan Concurrence was included in a Named Agreement (benoernd, specified), as stipulated in Article 1754 of the Civil Code. This agreement was in the Government Regulation Number 9 of 1995, concerning the Implementation of Savings and Loans by Cooperatives. It also stated that "Loans were the provision of money or bills equated based on an agreement between cooperatives and other parties, with the obligation to pay off the debt after a certain period, accompanied by the payment of several benefits".

Based on similarities to agreements, rights and obligations were regulated in loans, leading to the production of status bearer. According to $\mathrm{M}$. Fuady (2005), this status was abandoned by the parties, to create a condition known as "Default" (broken a promise). However, the government issued a Ministry of Cooperatives and MSMEs Regulation Number 20 / Per / M.UMKM/IX/2008 and Number 14 / Per / M.KUMKM / XII / 2009 concerning Assessment Health level of the Savings and Loans Cooperative, to state that an individual had breached business activities by failing a promise. This regulation divided members' categories or status as smooth, standard, doubtful, and jammed, before being finally declared to have failed the promise. The categories are then generally divided into several timeframe criteria.

Although a cooperative is philosophically a business entity used to improve its members' standard of living, an institution maintaining goodwill, such as a Guarantee agency, is still needed. This institution aims to ensure that members adequately pay loans and also form of cooperative responsibility, to utilize other substitutes. Although cooperatives and banks were different financial institutions, there was still no alterations in using a guaranteed department to maintain each party's faith in business activities. There were also no restrictions on the types of guaranteed institutions (Fiduciary, Dependent, Mortgage, Pawn, etc.) listed in the Laws. Therefore, the use of guaranteed institution was determined by each party involved, and adjusted to the amount of loan/credit provided by the Cooperative/ Bank.

Although the cooperative was protected using a guaranteed institution, the Savings and Loans approach to solve the problem of distributing funds was conducted through familial means compared to legal channels. This was reasonable due to being in line with the philosophy of cooperatives, which carried out their business activities based on the principles of kinship and mutual cooperation (Sri Purwanti et al., 2016).

\section{E. Forms of Revitalization of Savings and Loan Cooperative Financing as Efforts to Improve the State's Economy}

This study did not intend to revitalize cooperatives from a management perspective, due to making them inactive, as shown in the Ministry of 
Cooperatives and MSMEs Regulation Number 25/Per./M.KUKM/ IX/2015, concerning Cooperative Revitalization. The revitalization process in this study was divided into two, namely Cooperative income source management and Channelling fund approaches, through the use of financial and strategical techniques, respectively. The income source method was also linked to the applicable legal provisions in Indonesia, concerning Savings and Loans Cooperatives.

The revitalization process was further based on the perspective of Roscoe Pound legal theory, which stated that law was a tool of social engineering (Wignjosoebroto, 2008). Based on the study of Theresia Anita Christiani, "law had the consequence of changing and renewing the community, as a tool of social engineering" (Christiani, 2018). According to this perspective, the experts in this study stated that the theory of law was used as a solution to re-arrage the problematic legalization in the society. This indicated that social engineering basically included changes in the following areas, 1) Changes in social values, 2) Changes in social norms, 3) Changes in behavioral patterns, 4) Changes in organization, 5) Changes in the structure of social institution, 6) Changes in the society, 7) Changes in power and authority (including law enforcement), and 8) Changes in social interaction (Matnuh, 2017).

According to the statement above, the experts stated that law focused on the legal problems in the society, and gradually changed them. Therefore, the law as a social engineering tool was used to design a legal framework to the better financing system concept of savings and loans cooperatives.

\section{Revitalization of Financial Resource Management for Savings and Loans Cooperatives}

Revitalization of financial resource management was carried out by cooperatives, based on the distribution of funds to its members. The first type was aimed at strengthening the managerial power, as, internal strength was established when distributing funds to members. This strength ensured that the management was accountable, transparent, and obedient to the law on the associated organizational regulations.

The second revitalization aimed to make cooperatives have a mature strategy like a bank institution, without losing their basic essence as a symbol of the people's struggle. This was based on improving their standard of living, due to the principles of kinship and mutual cooperation. It was also necessary to prevent the Savings and Loans Cooperative not trapped by bad repayments from its members. Furthermore, the revitalization process was found to be very necessary, due to the Constitutional Court Decision Number 18 / PUU-XVII / 2019. This stated that in the event of a broken promise from a debtor, the case should be resolved before the court.

\footnotetext{
134 Yustlsla Volume 10 Number 2 (May-August 2021) $\quad$ Revltallzatlon of Fundlng for Savlngs and...
} 


\section{a. Approach to Management of Financial Resources for Savings and}

Loans Cooperatives.

This revitalization used the good corporate governance approach as a doctrine, to support the institutional system of business entities in carrying out their activities. This doctrine was adopted due to increasing economic efficiency, including all cooperative instruments, as well as selling and trust values of the community.

Good corporate governance clearly provided a structure for a code of ethics and organizational regulations, to achieve the objectives of business activities. In this study, the doctrine approach was based on 5 (five) indicators, namely Transparency, Accountability, Responsibility, Independence, as well as Fairness and Equality (M. Arief Effendi, 2009).

\section{i. Transparency}

Transparency is defined more as the openness of information, making decisions, and disclosing financial and non-financial information. It is often associated with the openness of reports within a business entity. In the context of this study, the intended transparency is that high-ranking cooperative officials need to have a strong heart to provide financial reports, as well as implementation activities and salary grant plans to all members of the savings and loan cooperative.

Transparency was not an obstacle for cooperative leaders to achieve their financial goals, although it supported the democratic aspect. Information disclosure on any policies related to finance fostered a sense of trust from non-high-ranking cooperative members to their officials. This led to increasing member participation in terms of the non-member communities' selling values, and also to the level of trust in meeting the obligations of borrowing users. Furthermore, the transparency of each financial policy also enriched opinions and criticism, as the organizational pattern of the cooperative reached a consensus after going through deliberation.

\section{ii. Accountability}

Accountability is defined as conformity, functions, structures, systems, and responsibilities of cooperative organs/parts, which enables efficient and effective management. It is further considered necessary to be applied in order to clarify the financial managerial journey between recorded and reported data to members, during meetings.

This indicator was also an aspect of the functional or organizational separation of the savings and loan cooperatives. Therefore, accountability was an indicator to keep savings and loan cooperatives away from conflicts of interest. One way to prevent 
this potential conflict of interest was to apply Standard Operating Procedures (SOP), and also a clear job description of each party.

\section{iii. Responsibility}

Responsibility is the total cooperative abilities of members in the organization. It is often associated with their compliance with laws, regulations, and Bylaws.

Cooperative members were responsible for carrying out obligations, regarding the capital aspects of all types of deposits that should be provided to savings and loan organization. A sense of responsibility and awareness to help one another was also needed among members. Furthermore, a good indicator of responsibility was observed from the honesty of high-ranking officials in carrying out their obligations, based on the approved financial plan at the Cooperative Member Meeting. Besides regular report provisions to members, they still did not commit acts that led to self-fraud.

\section{iv. Independence}

Independence is a condition where the savings and loan cooperatives are professionally managed without conflict of interest and influence/pressure from any party not abiding with the Bylaws, laws, and regulations. One conflict of interest that deserved consideration was the recruit of cooperative employees based on the procedures, mechanisms, and preparation of a savings and loan financial plan, free from members' pressure.

\section{v. Fairness and Equality}

This is defined as fair and equal treatments in meeting all the rights and obligations of members and stakeholders within the organization. The indicator also needs the savings and loan cooperatives to freely and structurally monitor all members, as stipulated in the Cooperative Bylaws. This also conducted the assumptions of results, regarding the supervision analyzed and discussed in the Cooperative Member Meeting.

This indicator needed the cooperative to have regular meetings with its members and employees, regarding the existence of affiliated parties that are users of the organizational structure. Therefore, they know and determine the limitations of the affiliated parties' authority, such as those with blood relations.

A good corporate governance approach to cooperative financial managerial was aimed at fostering a sense of law, and modernizing the organization without losing its essence as a business entity, based on the principles of kinship and mutual cooperation. 


\section{b. Approach to Distribution of Funds to Members of Savings and Loan Cooperatives.}

This type of approach is based on the aspects of the financing strategy provided to members. It does not eliminate the flexibility of savings and loan organization in lending funds to their members, although it is still an analytical form of the ability and accountability of cooperative members to their obligations. This indicated the intention of the approach as financial risk mitigation, based on the legal aspects being encountered by savings and loan cooperatives.

The strategy generally found in the aspect of financing was the 5C principle, which was better known in the banking world (Kasmir, 2009). Implementing the $5 \mathrm{C}$ was quite easy, due to these members being an integral part of the cooperative. The principles such as character, capacity, capital, and conditions, were easily analyzed by savings and loan cooperatives. Moreover, this was common when the members were MSME business actors, officially registered under the organization's membership, due to the efforts of the managerial aspects to carry out economic education.

The principle of " $5 \mathrm{P}$ " was also essential to the managerial strategies to achieve certain goals, according to Mintzberg (C. Dirgantoro, 2001). These were applied by the savings and loan cooperatives to carry out strategies in financing their members. The following is an explanation of these principles.

\section{i. Plan}

According to Mintzberg, planning includes a motion of reference, where a company adjusts to achieve an evaluation in making plans based on previous events. Furthermore, savings and loan cooperatives need to make a financial plan for its members, including several distributed funds, the estimated period for settling debtors' obligations, and the total amount of assets.

Based on previous planning events, the cooperative basically carried out an inventory of the debtor list, due to payment obligation and compliance category. This was divided based on the Ministry of Cooperatives and MSMEs Regulation Number 20/Per/M.UMKM/ IX/2008 and Number 14/Per/M.KUMKM/XII/2009, concerning the Health Level Assessment of savings and loan organization, namely current, substandard, doubtful, and jammed. In addition, this was accompanied by an inventory of guarantees carried out from debtors. It also determined the managerial or legal steps for each debtor, based on its category.

\section{ii. Pattern}

The planning carried out needs to be placed into a written regulation, making it a guide for all cooperative members in 
becoming an organizational structure. This aims to create a pattern or consistency, in order to develop legal certainty. The plan was also divided into short, medium or long-term, depending on the needs and the type of planning used by the savings and loan cooperative.

\section{iii. Position}

According to Mintzberg, "Position" was placed where a particular product or service met the offender, and was obtained to review aspects of the external environment. This indicated that companies should determine the intersection between the satisfaction of the offender, as well as the quantity of goods and services being provided.

Based on savings and loan cooperatives, this indicator was less effective, due to the business perspective being inward instead of outward. This indicated that position was cooperative for members. It also cooperated with other parties to maximize the value of their assets, without conflicting with the Laws and Regulations of the Minister of Cooperatives and MSMEs.

iv. Perspective

Although the operation of the savings and loan organization is not a business entity with a unit, it still portrayed the attributes to its members. However, this does not show that the indicator is useless in revitalizing financing. According to Mintzberg, it is defined as the process of maximizing the organizational system, in order to carry out planning. This indicated that the financial management system should support the managerial plans, due to the principles of good corporate governance being important.

v. Play.

This is a specific maneuver used to outwit the opponent or competitor of a company. In the context of savings and loan cooperatives, the competitor was an organizational culture. This attributes of this indicator includes the implementation of duties, as bearers of the rights and obligations of its members. It also indicated that the cooperative competed with itself, in order to become a better business entity, with each member acquiring the required benefits.

Mintzberg stated that the operation of the savings and loan cooperative contained 2 (two) factors as follows,

\section{Synergy of All Instruments Within the Cooperative}

The cooperative instrument is basically known to be its members, which contains those committed to improving their living standard and economic welfare. Furthermore, a cooperative contained several devices as shown below,

\footnotetext{
138 Yustlsla Volume 10 Number 2 (May-August 2021) Revltallzatlon of Fundlng for Savings and...
} 
a. Members Meeting: This is the highest authority in the cooperative, where all important decisions are made, such as the management selection, distribution of SHU (remaining results of operations), and the determination of the reserve funds. It is also a deliberation attended by all members, each possessing a vote used in making decisions. This meeting is held once a year, and often known as the Annual Members Meeting (RAT).

b. Supervisors: These are members of a cooperative elected through a meeting, with duties including the supervisions of the cooperative management and administration, managing performance, as well as auditing the managerial, financial, and physical conditions/inventory of the organization. Moreover, supervisors have to report the performances of the management during deliberations at Member Meetings.

c. Managers: They are generally responsible for carrying out the overall duties of the cooperative. The managers are often elected through a Members' Meeting, and also carry out their duties for 1 period.

d. Administrators: These are members of a cooperative appointed by the management, in order to perform the managerial duties of the organization.

These cooperative instruments were the devices or institutions being performed based on their nature, basis, and principles. Meanwhile, assumptions were made that these devices carried out constitutional mandate as the pillars of the state's economy, despite the clear existence of a mechanism in Law Number 25 of 1992 concerning Cooperatives, Ministry of Cooperatives and SMEs Regulation, and the Bylaws (ART).

\section{Strengthening Cooperative Capital}

Cooperative Business Capital practically originates from 2 (two) sources, namely Internal and External, as shown below,

\section{a. Internal Cooperative Capital}

(1) Principal savings are fixed deposits paid once, when registering as a member. These were not collected while still a member of the cooperative.

(2) Mandatory Savings are obligatory deposits paid by members at a predetermined cost. These were not withdrawn while still a member of the cooperative.

(3) Voluntary Savings are deposits stored in any amount, and are also retrieved at any time.

(4) Reserve Savings are part of the remaining results of operations (SHU), which are not distributed to members at 
any time. This is based on the agreement at the members' meeting.

\section{b. External Cooperative Capital}

(1) Grant is a gift from another party to the cooperative, which is in the form of cash or other inventory items.

(2) Loans are capitals provided to a cooperative in the form of agreement with other parties, to meet their financial needs.

The were the capitals necessary for the cooperative to carry out its duties as the pillars of the state's economy. Although the real challenges existed within the regulations, they were also observed based on the capital and commitment of its members. Therefore, cooperatives need other important instruments to support their operation, assuming that they had a risk mitigation system like a bank, without eliminating their essence as pillars of the state's economy.

\section{Revitalization of the Concept of Loan Agreements for Savings and Loans Cooperatives}

The purpose of revitalizing the loan agreement concept is to include several perspectives around the Legal Science of Engagement, through the distribution of funds to its members. This was placed at the beginning and the end, before the registration of members and the agreement of a loan.

The first concept involves the pre-contractual activities between the organizations and their members. In the Indonesian legal system, the precontract is better known as the "Memorandum of Understandings" (MoU), containing written general agreements from each party before entering into a contract (M. Fuady, 1994).

Based on the Anglo-Saxon/common legal system, the pre-contract is an inseparable part of the core contract. When there is a breach of contract, the aggrieved party is opportuned to file a default suit to the Court, in accordance with the Legal Science of Engagement. This is known as the Hard Law approach, which is achieved through statutory regulations. However, the Soft Law approach is carried out through ethics, in order to view the pre-contract in Indonesia.

Although this approach is ethical, it still binds the activities between the organizations (Savings and Loans Cooperatives) and the prospective debtors. In its philosophical setting, this approach binds the parties through moral burdens, in order to continuously carry out good faith, based on proper habits. Furthermore, the moral burden acts as a binding force for members of the savings and loan cooperatives, due to increasingly carrying out good faith from legal, ethical, and moral perspectives.

The second concept involved the formation of a special unit through a credit settlement committee, to settle bad loans obtained from the lending activities of a bank. However, there were similarities used in settling bad

$140 \quad$ Yustlsla Volume 10 Number 2 (May-August 2021) Revltallzatlon of Fundlng for Savings and... 
loans without going through legal procedures. This is in accordance with the Bank Indonesia Regulation Number 8/5/PBI/ 2006 concerning Banking Mediation. It stated that mediation was carried out by Bank Indonesia as the only mediator, due to the failure of the customer's financial demands. However, the task units carried out deliberations with the mediation, in order to reach a consensus, such as preventing both parties from settling their cases on legal channels. This deliberation was conducted by submitting the bad loan settlement offer from the savings and loan cooperatives to the debtors, with the members capable of negotiating the offer. The offers obtained from these cooperatives were in the form of loan restructurings, voluntary collection of guarantees from debtors, or interest deductions to borrowing members. Therefore, the deliberated results were placed into a special document, in the form of an agreement or written statement.

Based on the government's response to the Covid-19 pandemic, a countercyclical policy was established as a national economic stimulus, in order to limit the impact of the disease. This included the Regulation of Financial Services Authority (POJK) Number 48/POJK.03/2020 concerning Amendments to Financial Services Regulation Number 11/POJK.03/2020. In this regulation, there was a restructuring scheme for debtors to manage their cash flow, after being affected by the pandemic. The Regulation of the Financial Services Authority was also basically established to avoid free riders and moral hazard. However, there was a provision of the restructurings, such as a borrowing ceiling smaller than Rp 10 billion.

The provisions contained in the POJK were also basically applied by the organizations, with several adjustable changes to the needs and patterns of business activities. This application was conducted with a record of not exceeding the limit of a non-bank financial institution. A concrete example of exceeding the limitations of a non-bank institution was the implementation of higher interest rates than commercial banks. The largest rates for MSMEs is presently 3.5,, according to the credit base value issued by the Financial Service Authority (OJK) in 2021, with recommendations stating the these cooperatives should not exceed these limits $(\mathrm{OJK}, 2021)$.

The implementation of the higher interest rates involve the use of illegal debt collector, which was against the law. This increased the legal risk for savings and loan cooperatives, based on being considered as illegal financial institutions. Therefore the experts stated that the non-bank financial institutions should not exceed standard limitations.

\section{Conclusion}

Based on the discussion, the existence of cooperatives should be considered as pillars for improving the state's economy, due to the challenges posed after the Covid-19 Pandemic. Although the cooperative was an economical instrument in Indonesia, it was still portrayed as a symbol of the community resistance, as well as 
the struggle to improve living standards and eradicate poverty. It was also observed as an alternative for MSME actors and the society, in order to develop businesses concerned with financial services. Therefore, cooperatives were used as sources of developing MSMEs. Furthermore, a financial revitalization process was needed by the savings and loan cooperatives, with the procedures carried out with 2 (two) approaches. Firstly, revitalizing financial resources through an income source management approach, by implementing Good Corporate Governance and specific strategies in savings and loan cooperatives, as outlined in SOPs and regulations. Secondly, revitalizing the concept of loan agreements through pre-contracting and formation of special unit, which resolved bad loans from the debtor to achieve a consensus.

\section{BIBLIOGRAPHY:}

\section{Books with an author:}

Arifin Sitio dan Halomoan Tamba. (2001). Koperasi dan Praktek. Jakarta: Erlangga

Crown Dirgantoro. (2001). Manajemen Stratejik. Jakarta: PT Grasindo.

E. Fernando M. Manullan. (2007). Menggapai Hukum Berkeadilan: Tinjauan Hukum Kodrat dan Antinomi Nilai. Jakarta: Kompas.

Henry Campbell. (1991). Black's Law Dictionary. Minnesota: West Publishing Company.

International Monetary Fund. (2015). Financing for Development: Revisiting The Moneterrey Consensus. Washington, DC: IMF.

John Gilissen \& Frits Gorle. (2005). Sejarah Hukum: Suatu Pengantar. Bandung: Refika Aditama.

Kasmir. (2009). Bank dan Lembaga Keuangan Lainnya. Jakarta: PT Raja Grafindo Persada.

Katherine C. Deville, et.all. (2007). Farmer Cooperatives Statistics : 2006. U.S.A of Departement of Agriculture: Washington, DC.

Lawrence M. Friedman (2001). Hukum Amerikca: Sebuah Pengantar, Translated by Wisnu Basuki. Jakarta: Tatanusa.

Mariam Darus Bardulzaman. (1994). Aneka Hukum Bisnis. Bandung: Penerbit Alumni.

Muhamad Arief Effendi. (2009). The Power of Good Corporate Governance: Teori dan Implementasi. Jakarta: Salemba Empat.

Michael P. Todaro. (1999). Pembangunan Ekonomi Di Dunia Ketiga. Jakarta: Erlangga.

Munir Fuady. (1994). Hukum Bisnis dalam Teori dan Praktik. Buku Ke-4. Bandung: Citra Aditya Bhakti.

Munir Fuady. (2005). Pengantar Hukum Bisnis: Menata Bisnis Modern di Era Global. Edisi Revisi. Bandung: PT Citra Aditya Bakti.

Pandji Anoraga \& Sudantoko Djoko. (2002). Koperasi Kewirausahaan dan Usaha Kecil. Semarang: Rineka Cipta.

$142 \quad$ Yustlsla Volume 10 Number 2 (May-August 2021) $\quad$ Revltallzatlon of Fundlng for Savings and... 
Peter Mahmud Marzuki. (2009). Penelitian Hukum. Jakarta: Kencana Prenada Media Group.

Revrisond Baswir. (2000). Koperasi Indonesia. Edisi Pertama. Yogyakarta: BPFE UGM.

Soetandyo Wignjosoebroto. (2002). Hukum: Paradigma, Metode, dan Dinamika Masalahnya. Jakarta: Elsam

Sadono Sukirno. (2002). Pengantar Teori Makroekonomi. Jakarta: PT Raja Grafindo Persada.

S. Wignyosebroto. (1994). Hukum dalam Masyarakat (Perkembangan dan Masalah Sebuah Pengantar ke Arah Kajian Sosiologi Hukum), Malang: Bayumedia Publishing.

Zainuddin Ali. (2015). Metode Penelitian Hukum. Jakarta: Sinar Grafika.

\section{Journal articles:}

Arin Ramadhiani Soleha, (2020). Kondisi UMKM Masa Pandemi Covid-19 Pada Pertumbuhan Ekonomi Krisis Serta Program Pemulihan Ekonomi Nasional. Jurnal Teuku Umar. Vol. 6. No.2. doi: https://doi.org/10.35308/ekombis.v6i2.2881.

Danil Syaputra dan Supiah Ningsih, (2020). Pengaruh Kredit Perbankan Konvensional Dan Pembiayaan Perbankan Syariah Terhadap Pertumbuhan Ekonomi Indonesia. HUMAN FALAH: Jurnal Ekonomi dan Bisnis Islam. Vol. 1. No. 1. doi: http://jurnal. uinsu.ac.id/index.php/humanfalah/article/view/6806.

E. G. Nourse (1922). The Economic Philosogphy of Co-operation. The American Economic Review. Vol. 12. No. 4. doi: https://www.jstor.org/stable/pdf/1804796.pdf.

Fiqih Putra Arifandy, (2020). Peran Koperasi Dalam Meningkatkan Perekonomian Masyarakat Nelayan: Perspektif Modal Kerja. Jurnal Akademi Akuntansi. Vol. 3. No. 1. doi: https://doi.org/10.22219/jaa.v3i1.11665.

Harpani Matnuh, (2017). Law as a Tool of Social Engineering. Adcances in Social Science. Education and Humanities Research (ASSEHR), Vol. 147. doi: https://dx.doi. org/10.2991/icsse-17.2018.28.

Johannes Michelsen, (1994). The Rationales of Cooperatives Organizations: Some Suggestions from Scandinavia. Annuals of Public and Cooperatives Economic. Vol. 65. Issue. 1. doi: https://doi.org/10.1111/j.1467-8292.1994.tb01504.x.

Ronald Rateiwa \& Meshach J. Aziakpono, (2017). Non-bank institutions and economic growth: Evidence From Africa's Three Largest Economies. South African Journal of Economic and Management Sciences. Vol. 20. No. 1. doi: https://doi.org/10.4102/ sajems.v20i1.1545.

Sri Purwanti, (2016). Kajian Pengelolaan Dana Koperasi Simpan Pinjam Konvensional di Kota Semarang. Jurnal Dinamika Sosial Budaya. Vol. 18. No. 1. doi: http://dx.doi. org/10.26623/jdsb.v18i1.564.

Zainal Arifin Hoesein, (2016). Peran Negara Dalam Pengembangan Sistem Ekonomi Kerakyatan Menurut UUD 1945. Jurnal Hukum IUS Quia Iustum. Vol. 23. No. 3. doi: https://doi.org/10.20885/iustum.vol23.iss3.art8. 


\section{Websites:}

Antonius Purwanto. (2020). Potret dan Tantangan UMKM di Indonesia. Availabel online form:https://kompaspedia.kompas.id/baca/paparan-topik/potret-dantantangan-umkm-di-indonesia. [Accessed March 24 2021].

Bank Indonesia. (2021). Laporan Bank Indonesia Tahun 2009, 2010, 2011, 2012, 2013, 2014, 2015, 2016, 2017, 2018, 2019, dan 2020. Available online form: https:// www.bi.go.id/id/publikasi/laporan/default.aspx?Kategori=laporan $\% 20$ perekonomian\&Periode=tahunan. [Accessed March 10 2021].

CNN Indonesia. (2020). BPS Catat Pendapatan Per Kapita Masyarakat Turun Rp286 ribu. Available online form: https://www.cnnindonesia.com/ ekonomi/20201215140102-92-582350/bps-catat-pendapatan-per-kapitamasyarakat-turun-rp286-ribu. [Accessed Febuary 11 2021].

International Cooperatives Alliance. (2021). What is Cooperatives. Availabel online form: https://www.ica.coop/en/cooperatives/what-is-a-cooperative. [Accessed August 2 2021].

RM.id. (2020). Menkop Sayangkan Kontribusi Koperasi Ke Ekonomi Masih Rendah. Available online form: https://rm.id/baca-berita/government-action/41062/menkopsayangkan-kontribusi-koperasi-ke-ekonomi-masih-rendah. [Accessed March 18 2021].

Otoritas Jasa Keuangan. (2021). Suku Bunga Dasar Kredit. Available online form: https:// www.ojk.go.id/id/kanal/perbankan/Pages/Suku-Bunga-dasar.aspx. [Accessed May 30 2021].

144 Yustlsla Volume 10 Number 2 (May-August 2021) Revltallzatlon of Fundlng for Savings and... 